Volume 5 Issue 1, March 2020: pp. 100-108 . Copyright @ LamLaj. Faculty of Law, Lambung Mangkurat University, Banjarmasin, South Kalimantan, Indonesia. ISSN: 2502-3136 | e-ISSN: 2502-3128. Open Access at: http: / /lamlaj.ulm.ac.id

\title{
PERLINDUNGAN HUKUM DATA AGUNAN DEBITUR DALAM PERSPEKTIF KERAHASIAAN PERBANKAN
}

\author{
Muhammad Erham Amin ${ }^{1}$, Noor Hafidah ${ }^{2}$ \\ Faculty of Law, University of Lambung Mangkurat \\ Jl.Brigjen H. Hassan Basry Banjarmasin 70124 \\ Telp/Fax:+62-4321658Email:muhammad.erham@ulm.ac.id \\ Faculty of Law, University of Lambung Mangkurat \\ Jl.Brigjen H. Hassan Basry Banjarmasin 70124 \\ Telp/Fax: +62-4321658Email: hafidahnoor@gmail.com
}

Submitted :02/15/2020 Reviewed: 21/03/2020 Accepted: 31/03/2020

\begin{abstract}
Registration of Fiduciary Security since the issuance of Government Regulation No. 21 of 2015 concerning FIDUCIA GUARANTEE REGISTRATION PROCEDURES AND COST OF MAKING FIDUSIA ASSETS are an obligation and obligation as a condition of a fiduciary agreement and as a form of implementation of the principle of publicity. In the online Fiduciary registration procedure, there are stages of searching data (or the term in practice is "buying data") which is charged a fee of fifty thousand rupiahs (IDR 50,000.00). If the user chooses the searching data option, a number of data related to debtor collateral will appear, such as the form of collateral, who is the creditor, and data on the value of the guarantee. It becomes a question when debtor collateral data is linked with the bank as the creditor. Is collateral data that can be accessed by users consisting of Notary, Corporate (consisting of banks and non-banks), and Retail (consisting of individuals and business entities) part of bank confidentiality? Debtor data in the bank secrecy provisions contained in the Banking Law can only be disclosed to certain parties for certain reasons as well. Therefore it is necessary to study the debtor collateral data in relation to the provisions of banking secrecy and protection of banks because this pertains to banks as creditors
\end{abstract}

Keywords: collateral data; bank secrets

Abstrak:Pendaftaran Jaminan Fidusia sejak dikeluarkannya Peraturan Pemerintah No. 21 Tahun 2015 tentang TATA CARA PENDAFTARAN JAMINAN FIDUSIA DAN BIAYA PEMBUATAN AKTA JAMINAN FIDUSIA menjadi sebuah kewajiban dan keharusan sebagai syarat perjanjian fidusia dan sebagai wujud implementasi asas publisitas. Dalam prosedur pendaftaran Fidusia secara online terdapat tahapan searching data (atau istilah dalam praktek adalah "beli data") yang dibebani 
biaya sebesar lima puluh ribu rupiah (Rp 50.000,00). Apabila user memilih pilihan searching data tersebut, maka sejumlah data terkait agunan debitur akan muncul, seperti bentuk agunan, siapa yang menjadi kreditur, dan data nilai penjaminan. Menjadi sebuah pertanyaan ketika data agunan debitur dikaitkan dengan pihak bank selaku kreditur. Apakah data agunan yang dapat di akses oleh user yang terdiri dari Notaris, Korporat (terdiri dari bank dan non bank) dan Retail (terdiri dari perorangan dan badan usaha) merupakan bagian dari keterangan rahasia bank? Data debitur dalam ketentuan rahasia bank yang terdapat dalam UU Perbankan hanya dapat dibuka kepada pihak pihak tertentu dengan sebab yang tertentu pula. Oleh karena itu perlu kajian terhadap data agunan debitur dalam kaitanya dengan ketentuan rahasia perbankan dan perlindungan terhadap bank, karena hal ini bersinggungan dengan perbankan selaku kreditur.

Kata kunci : data agunan; rahasia bank

\section{PENDAHULUAN}

Definisi normatif Jaminan Fidusia sebagaimana tersebut dalam Pasal 1 UndangUndang No. 42 Tahun 1999 tentang Jaminan Fidusia adalah Jaminan Fidusia merupakan hak jaminan atas benda bergerak baik yang berwujud maupun yang tidak berwujud dan benda tidak bergerak khususnya bangunan yang tidak dapat dibebani hak tanggungan sebagaimana dimaksud dalam Undangundang Nomor 4 Tahun 1996 tentang Hak Tanggungan yang tetap berada dalam penguasaan Pemberi Fidusia, sebagai agunan bagi pelunasan utang tertentu, yang memberikan kedudukan yang diutamakan kepada Penerima Fidusia terhadap kreditor lainnya.

Untuk lahirnya jaminan fidusia sebagai sebuah hak jaminan yang memberikan kedudukan yang diutamakan kepada penerima fidusia terlebih dahulu harus memenuhi ketentuan tentang pendaftaran jaminan fidusia yang menjadi salah satu karakteristik dalam jaminan fidusia. Pendaftaran jaminan fidusia menjadi suatu keharusan dalam sebuah perjanjian jaminan fidusia karena apabila pendaftaran ini tidak dipenuhi maka perjanjian jaminan fidusia di anggap belum lahir (pasal 14 ayat 3 Undang-Undang No. 42 Tahun 1999 tentang Jaminan Fidusia).

Ketentuan pendaftaran jaminan fidusia tertuang di dalam Pasal 11 ayat 1 UndangUndang No. 42 Tahun 1999 tentang Jaminan Fidusia (selanjutnya disebut dengan UUJF) yang menyatakan bahwa "benda yang dibebani dengan Jaminan Fidusia wajib didaftarkan".

Pada awalnya pendaftaran jaminan fidusia dilakukan di kantor pendaftaran jaminan fidusia yang berada dalam lingkup Departemen Kehakiman (vide pasal 12 ayat 1 sampai dengan ayat 4 UUJF). Akan tetapi karena terdapat banyak kendala dalam pelaksanaan pendaftaran jaminan fidusia akhirnya pemerintah mengeluarkan kebijakan yang mengatur tentang tata cara pendaftaran fidusia secara elektronik atau secara online.

Pendaftaran fidusia secara online merupakan kebijakan Direktorat Jenderal Administrasi Umum (Ditjen AHU) Kementerian Hukum dan HAM yang secara teknis menggunakan aplikasi Si Fidu (fidusia. ahu.go.id), dan merupakan terobosan penting 
dalam manajemen pendaftaran fidusia yang sebelumnya dilakukan secara manual.

Kebijakan pendaftaran secara elektronik ini pada awalnya tertuang di dalam Peraturan Menteri Hukum dan Hak Asasi Manusia Republik Indonesia Nomor 9 Tahun 2013 Tentang Pemberlakuan Pendaftaran Jaminan Fidusia Secara Elektronik (selanjutnya disebut Permenkumham No. 9 Tahun 2013) dan Peraturan Menteri Hukum dan Hak asasi Manusia Republik Indonesia Nomor 10 Tahun 2013 Tentang Tata Cara Pendaftaran Jaminan Fidusia Secara Elektronik (selanjutnya disebut Permenkumham No. 10 Tahun 2013) dalam rangka meningkatkan pelayanan kepada masyarakat yang memerlukan jasa hukum di bidang jaminan fidusia.

Permenkumham No 9 Tahun 2013 dan Permenkumham No. 10 Tahun 2013 pada akhirnya disempurnakan dengan diterbitkannya Peraturan Pemerintah (PP) No. 21 Tahun 2015 tentang Tata Cara Pendaftaran Jaminan Fidusia dan Biaya Pembuatan Akta Jaminan Fidusia dikeluarkan oleh pemerintah sejak bulan April tahun 2015 yang lalu, yang secara garis besar berisi ketentuan tentang tata cara pendaftaran Jaminan Fidusia secara elektronik. Terkait pendaftaran jaminan fidusia secara online Kementerian Hukum dan HAM diwakili oleh Direktorat Jenderal Administrasi Umum (Ditjen AHU) menerapkan kebijakan baru terkait para pihak yang dapat melakukan pendaftaran fidusia, yaitu Notaris, Korporasi dan Ritel. Kebijakan mengenai para pihak yang dapat melakukan pendaftaran fidusia ini menimbulkan persoalan hukum yang bersentuhan dengan lembaga perbankan. Persoalan tersebut terkait dengan pengisian kolom beli data atau searching data. Dalam sistem pendaftaran fidusia secara online terdapat beberapa tahapan yang salah satu tahapannya adalah pencarian data atau searching data.

Kebijakan tersebut berimplikasi dapat diaksesnya data-data nasabah yang ada hubungannya dengan penjaminan. Ketika data nasabah dapat di akses oleh para pihak (yang menurut peraturan menteri berwenang untuk mengisi pendaftaran fidusia secara online, yaitu Notaris, Korporate dan Retail), maka pada titik ini lah terjadi persinggungan dengan ranah hukum perbankan, khususnya kerahasiaan bank.

Para pihak yang melakukan pencarian data ketika mengisi pendaftaran jaminan fidusia online secara teknis akan "meng-klik" searching data, dan akan muncul sejumlah informasi terkait data agunan nasabah dan kreditur terkait, yang dalam ini adalah pihak bank.

Persoalan yang timbul selanjutnya adalah Apakah data agunan yang tertampil dalam aplikasi pendaftaran jaminan fidusia secara online dapat dikatakan sudah melanggar dengan ketentuan rahasia perbankan, sebagaimana di atur dalam Pasal 40 Undangundang No. 10 Tahun 1998 tentang Perbankan, mengingat para pihak yang mengakses aplikasi pendaftaran fidusia secara online terdiri dari banyak pihak. Sementara terkait dengan ketentuan rahasia bank, hanya pihak pihak tertentu yang dapat mengakses segala sesuatu terkait informasi keuangan nasabah dan dalam keadaan tertentu pula.

\section{METODE}

Penelitian ini merupakan penelitian normatif, dengan menggunakan pendekatan perundang-undangan sebagai pisau analisis untuk menyelesaikan masalah hukum yang 
ada. Sifat penelitian adalah preskriptif dan bahan hukum yang di gali adalah bahan hukum primer dan bahan hukum sekunder. Bahan hukum primer antara lain adalah :

1. Burgerlijk Wetboek,

2. Undang-Undang No. 10 Tahun 1998 tentang Perubahan atas Undang-Undang No. 7 Tahun 1992 tentang Perbankan

3. Undang Undang No. 42 Tahun 1999 tentang Jaminan Fidusia.

4. Peraturan Menteri Hukum dan Hak Asasi Manusia Republik Indonesia Nomor 9 Tahun 2013 Tentang Pemberlakuan Pendaftaran Jaminan Fidusia Secara Elektronik

5. Peraturan Menteri Hukum dan Hak asasi Manusia Republik Indonesia Nomor 10 Tahun 2013 Tentang Tata Cara Pendaftaran Jaminan Fidusia Secara Elektronik.

6. Peraturan Pemerintah No. 21 Tahun 2015 tentang Tata Cara Pendaftaran Jaminan Fidusia dan Biaya Pembuatan Akta Jaminan Fidusia

\section{ANALISIS DAN PEMBAHASAN}

Peneliti akan memulai pembahasan dengan menganalisa konsep rahasia bank dan kemudian mengharmonisasikan dengan ketentuan terkait rahasia bank sebagaimana di atur dalam UU Perbankan (sebagai langkah pendekatan perundang-undangan) dan data agunan yang terdapat dalam aplikasi pendaftaran jamina fidusia secara on line ( $\mathrm{Si}$ Fidu) yang dapat diakses oleh pihak yang sudah ditentukan.

Definisi normatif Rahasia Bank sebagaimana tersebut dalam Pasal 1 angka 28 Undang-undang No 10 Tahun 1998 tentang Perubahan atas Undang-Undang No. 7 Tahun 1992 tentang Perbankan (selanjutnya disebut UU Perbankan) adalah segala sesuatu yang dengan keterangan mengenai nasabah penyimpan dan simpanannya.

Definisi normatif rahasia bank sebagaimana tersebut dalam pasal $28 \mathrm{UU}$ Perbankan berbeda dengan definisi normatif rahasia bank sebagaimana tersebut di dalam UU No. 7 Tahun 1992 tentang Perbankan. Pasal 1 angka 16 Undang-Undang No.7 Tahun 1992 tentang Perbankan menyatakan bahwa rahasia bank adalah segala sesuatu yang berhubungan dengan keuangan dan hal-hal lain darinasabahbank yang menurutkelaziman dunia perbankan wajib dirahasiakan.

Pasal 16 UU No. 7 Tahun 1992 mengandung makna kontekstual bahwa ruang lingkup kerahasiaan bank sangat yang luas, baik menyangkut objek maupun kedudukan nasabahnya. Hal hal yang termasuk rahasia bank bahwa yang dilindungi rahasia bank bukan hanya keterangan dan keadaan keuangan nasabah penyimpan dana dan simpanannya, melainkan juga keterangan keuangan nasabah debitur atau pinjamannya. Sementara Pasal 8 UU Perbankan membatasi atau mempersempit hal-hal yang wajib dirahasiakan oleh bank, yakni sebatas pada keterangan dan keadaan keuangan nasabah penyimpan dan simpanannya. Sehingga keterangan dan keadaan keuangan nasabah selain sebagai nasabah penyimpanan bukan merupakan keterangan yang wajib dirahasiakan oleh bank.

Pengertian rahasia bank sebagaimana tersebut di atas ditafsirkan secara lebih jelas oleh para ahli hukum. Djumhana menyatakan bahwa rahasia bank adalah segala hal keterangan yang terkait dengan keuangan, dan hal-hal lain dari nasabah bank yang menurut kelaziman dunia perbankan tidak boleh secara terbuka diungkapkan kepada 
pihak masyarakat. Adapun maksud menurut kelaziman wajib dirahasiakan oleh bank, adalah seluruh keterangan terkait data dan informasi apa pun mengenai segala sesuatu yang berhubungan dengan keuangan, dan halhal lain dari orang, dan badan yang diketahui oleh bank karena kegiatan usahanya ${ }^{1}$. Selain itu Kasmir berpendapat bahwa rasio logis pemberlakuan ketentuan tentang rahasia bank patut untuk diatur karena pada dasarnya kegiatan dunia perbankan adalah mengelola uang masyarakat (menghimpun dan menyalurkan dana masyarakat), sehingga bank wajib menjaga kepercayaan yang diberikan masyarakat. Bank wajib menjaga keamanan uang tersebut agar benarbenar aman. Agar keamanan uang nasabahnya terjamin, pihak perbankan dilarang untuk memberikan keterangan yang tercatat pada bank tentang keadaan keuangan dan hal -hal lain dari nasabahnya. Dengan kata lain, bank harus menjaga rahasia tentang keadaan keuangan nasabah dan apabila melanggar kerahasiaan ini perbankan akan dikenakan sanksi. ${ }^{1}$

Dari konsep rahasia bank yang tersebut dalam UU Perbankan dan doktrin para ahli hukum, makna rahasia bank yang dapat peneliti sampaikan adalah bahwa yang dimaksud dengan rahasia bank adalah kerahasian terhadap dokumen dan informasi keuangan nasabah. Kajian rahasia bank berdasarkan UU Perbankan harus berpijak pada ketentuan Pasal 40 UU Perbankan. Pasal 40 UU Perbankan menyatakan bahwa "bank wajib merahasiakan keterangan mengenai Nasabah Penyimpan dan simpanannya, kecuali dalam hal sebagaimana dimaksud

1 Muhammad Djumhana. 1996. Rahasia Bank (Ketentuan dan Penerapannya di Indonesia), Bandung : Citra Aditya Bakti. hal.111. dalam Pasal 41 , Pasal 41A. Pasal 42, Pasal 43, Pasal 44, dan Pasal 44A. ${ }^{2}$

Pasal 40 UU Perbankan mengandung penafsiran bahwa "bank "berkewajiban" untuk tidak menyampaikan kepada pihak lain segala sesuatu terkait data nasabah penyimpan dan simpanannya, kecuali terhadap keadaan sebagaimana yang tersebut dalam ketentuan pasal 41, pasal 41a, pasal 42, pasal 43, pasal 44 dan pasal 44a". Sebagaimana diketahui nasabah perbankan dibedakan antara nasabah penyimpan dana dan nasabah debitur. Terkait dengan hal tersebut Pasal 40 UU Perbankan mengandung penegasan bahwa data nasabah yang wajib dirahasiakan hanya nasabah penyimpan dana, bukan nasabah debitur.

Pasal 41, pasal 41a, pasal 42, pasal 43, pasal 44 dan pasal 44a sebagaimana tersebut dalam pasal 40 UU Perbankan merupakan ketentuan yang menjadi dasar penyimpangan atau dapat ditolerirnya kerahasiaan perbankan.

Ketentuan yang mengandung makna pengecualian pemberlakuan ketentuan rahasia bank dijabarkan sebagai berikut

1. Pasal 41 UU Perbankan menyatakan bahwa "untuk kepentingan perpajakan, Pimpinan Bank Indonesia atas permintaan Menteri Keuangan berwenang mengeluarkan perintah tertulis kepada bank agar memberikan keterangan dan memperlihatkan buktibukti tertulis serta surat-surat mengenai keadaan keuangan Nasabah Penyimpan tertentu kepada pejabat pajak". Unsur penting yang terkandung dalam pasal 41 UU Perbankan menurut hemat peneliti adalah bahwa dalam hal terjadi permasalahan yang ada hubungannya

2 Kasmir. 2008. Bank dan Lembaga Keuangan Lainnya. Jakarta : Raja Grafindo persada. hal. 57 
dengan Perpajakan, pemegang otoritas tertinggi perbankan yang dalam hal ini adalah Pimpinan Bank Indonesia dengan persetujuan dari Menteri Keuangan dapat memberikan perintah agar bank memberikan keterangan terkait keuangan nasabah penyimpanan. Artinya dalam hal terjadi kasus perpajakan ketentuan pasal 40 UU Perbankan dapat disimpangi untuk kepentingan Negara atau kepentingan umum.

2. Pasal 41a ayat 1 UU Perbankan: Untuk penyelesaian piutang bank yang sudah diserahkan kepada Badan Urusan Piutang dan Lelang Negara Panitia Urusan Piutang Negara, Pimpinan Bank Indonesia memberikan izin kepada pejabat Badan Urusan Piutang dan Lelang Negara/Panitia Urusan Piutang Negara untuk memperoleh keterangan dari bank mengenai simpanan Nasabah Debitur. Pasal 4la UU Perbankan ini merupakan pasal tambahan dalam UU Perbankan, karena ketentuan pasal 4la ini pada Undang-Undang Perbankan No 7 Tahun 1992 belum diatur. Kalau sebelumnya pasal 41 UU Perbankan terkait dengan kerahasiaan dokumen dan informasi nasabah debitur, maka ketentuan UU Perbankan pasal 41 huruf a ayat 1 terkait dengan kerahasiaan keterangan dokumen nasabah debitur. Unsur yang dapat disimpulkan dari ketentuan UU Perbankan Pasal 41 huruf a ayat 1 bahwa dalam hal penyelesaian hutang piutang antara bank dan nasabah debitur yang penyelesaiannya telah menjadi kewenangan Badan Urusan Piutang dan Lelang Negara Panitia Urusan Piutang Negara, otoritas tertinggi perbankan dalam hal ini Pimpinan Bank Indonesia dapat memberikan ijin kepada Badan Urusan Piutang dan Lelang Negara Panitia Urusan Piutang Negara untuk meminta keterangan terkait keuangan nasabah debitur yang bermasalah pada bank terkait. Pasal 41a ayat 2 UU Perbankan : Izin sebagaimana dimaksud dalam ayat (1) diberikan secara tertulis atas permintaan tertulis dari Kepala Badan Urusan Piutang dan Lelang Negara/ Ketua Panitia Urusan Piutang Negara. Unsur penting yang terkandung di dalam pasal 41 a ayat 2 UU Perbankan adalah dalam rangka mendapatkan keterangan keuangan nasabah debitur, Kepala Badan Urusan Piutang dan Lelang Negara/ Ketua Panitia Urusan Piutang Negara dapat mengajukan permohonan secara tertulis kepada Pimpinan Bank Indonesia, dan sebagai tindaklanjutnya Pimpinan Bank Indonesia akan memberikan izin secara tertulis berdasarkan adanya surat permintaan. Sehingga unsur penting di sini adalah bahwa apabila tidak ada permintaan secara tertulis dari Kepala Badan Urusan Piutang dan Lelang Negara/Ketua Panitia Urusan Piutang Negara maka Pimpinan Bank Indonesia tidak akan memberikan izin terkait keterangan keuangan nasabah debitur. Pasal 41a ayat 3 UU Perbankan: Permintaan sebagaimana dimaksud dalam ayat (2) harus menyebutkan nama dan jabatan pejabat Badan Urusan Piutang dan Lelang Negara/Panitia Urusan Piutang Negara, nama Nasabah Debitur yang bersangkutan dan alasan diperlukannya keterangan." "sicép. Unsur yang terkandung dalam pasal 41 a ayat 3 adalah terkait hal hal apa yang harus tercantum di dalam surat permohonan ijin untuk mengetahui keterangan keuangan nasabah debitur 
yang bermasalah, yaitu nama pejabat Kepala Badan Urusan Piutang dan Lelang Negara/Ketua Panitia Urusan Piutang Negara serta nama nasabah debitur terkait.

3. Pasal 42 ayat 1 UU Perbankan menyatakan untuk kepentingan peradilan dalam perkara pidana, Pimpinan Bank Indonesia dapat memberikan izin kepada polisi, jaksa, atau hakim untuk memperoleh keterangan dari bank mengenai simpanan tersangka atau terdakwa pada bank. Pasal 42 ayat 1 UU Perbankan mengandung makna tekstual yang sangat jelas terkait pengecualian kerahasiaan bank apabila terdapat perkara pidana yang ada sangkut pautnya dengan nasabah penyimpan dana yang menjadi tersangka.

4 Pasal 42 a UU Perbankan, yang merupakan ketentuan yang tidak di atur dalam UU No. 7 Tahun 1992 tentang Perbankan, menyebutkan bahwa bank wajib memberikan keterangan sebagaimana dimaksud dalam pasal 41, pasal 41a dan pasal 42. Penjelasan pasal 42 menurut UU Perbankan sudah cukup jelas. Menurut hemat peneliti pasal 42 a UU Perbankan mengandung makna penegasan bahwa bank mempunyai kewajiban untuk memberikan keterangan kepada para pihak terkait sebagaimana yang telah ditetapkan oleh UU Perbankan.

Kesimpulan yang dapat ditarik dari analisa pasal 41, pasal 41a, pasal $42 \mathrm{UU}$ Perbankan adalah bahwa kerahasiaan bank dapat dibuka apabila nasabah penyimpan atau nasabah debitur terkait dengan masalah perpajakan, penyelesaian sengketa hutang piutang dan perkara pidana. Sementara para pihak yang diberikan kewenangan untuk dapat mengajukan permohonan permintaan akses keterangan keuangan nasabah penyimpan dan nasabah debitur adalah petugas perpajakan, pejabat urusan piutang dan lelang negara, polisi, jaksa dan hakim. Untuk keperluan tersebut di atas maka bank dalam hal ini memiliki kewajiban untuk menyampaikan informasi-informasi terkait keuangan nasabah sebagaimana diminta oleh para aparat pemerintah yang telah diberi kewenangan. Pun termasuk didalamnya dalam hal perkara perdata antar bank dengan nasabahnya, direksi bank yang bersangkutan dapat menyampaikan informasi terkait keadaan keuangan nasabah (baik nasabah penyimpan ataupun juga nasabah debitur) kepada pihak pengadilan.

Terkait dengan data agunan nasabah yang menjadi bagian dari pendaftaran jaminan fidusia secara online yang, apakah telah bersinggungan dengan ketentuan rahasia bank sehingga merugikan lembaga perbankan, peneliti menyatakan bahwa data agunan yang diunggah oleh ditjen AHU melalui aplikasi pendaftaran fidusia secara online dapat merugikan lembaga perbankan.

Kalau dikatakan bahwa data agunan yang terdapat dalam aplikasi pendaftaran jaminan fidusia secara online bersinggungan dengan kerahasiaan bank adalah benar adanya. Persinggungan terletak pada para pihak yang dapat mengakses aplikasi pendaftaran jaminan fidusia secara online. Para pihak yang dapat mengakses pendaftaran fidusia secara online adalah notaris, korporate dan ritel (selanjutnya disebut para user). Para user ini apabila dihubungkan dengan para pihak sebagaimana yang di maksud dalam pasal 41, pasal 41a dan pasal 42 UU Perbankan, maka para user tersebut tidak termasuk dalam para pihak yang dapat melakukan dan meminta akses data nasabah sebagaimana dimaksud 
dalam UU Perbankan.

Oleh karena para user dalam pendaftaran fidusia online tidak termasuk di dalam para pihak yang tersebut dalam UU Perbankan logika berpikir yang muncul adalah atas data agunan yang dapat diakses oleh para user tersebut dapat dikatakan sebagai pelanggaran terhadap rahasia perbankan dan ini merugikan nasabah atau pun lembaga perbankan itu sendiri.

Akan tetapi jika dipandang dari optik perlindungan terhadap kreditur, maka data agunan yang dapat di akses oleh para user tersebut dapat memberikan kepastian bahwa atas barang yang dijadikan agunan tersebut tidak bermasalah, dalam ini tidak terjadi tumpang tindih jaminan atau jaminan ulang (seperti fidusia ulang).

Dalam perspektif yang lain, jika dipandang dari sisi subjek hukumnya (yang dalam hal ini adalah nasabah), data agunan yang terdapat dalam aplikasi pendaftaran fidusia online tersebut tidak termasuk rahasia bank, karena rahasia bank sebagaimana maksud dalam pasal 40 UU Perbankan adalah segala sesuatu keterangan keuangan milik nasabah penyimpan dana dan simpanannya. Meskipun pasal 41 UU Perbankan ada hubungannya dengan nasabah debitur, hal ini merupakan pengecualian. Peneliti berpendapat bahwa seyogyanya nasabah debitur juga tercover sebagai pihak yang harus dirahasiakan keuangannya dalam pasal 40 UU Perbankan, atau sebagaimana tercantum di dalam pasal 16 UU No. 7 Tahun 1992 tentang Perbankan. Dalam Pasal 16 keterangan terkait rahasia bank tersebut tidak saja meliputi nasabah penyimpan dana dan simpanannya akan tetapi meliputi pula nasabah debitur. Data agunan yang dapat diakses para user hanya mencantumkan nama nasabah berikut rekam agunan yang telah didaftarkan. Sehingga dalam hal ini tidak terkait dengan data keuangan nasabah penyimpan dana, justru yang berkepentingan dalam hal ini adalah nasabah debitur.

Sebagai benang merah apakah akses data agunan dalam pendaftaran fidusia secara online melanggar ketentuan rahasia bank dapat dilihat dalam tataran an sich. Kalau di lihat dalam tataran pengertian an sich, akses informasi perbankan (dalam hal ini data agunan nasabah dan debiturnya (yang kebanyakan adalah bank)) dalam pendaftaran fidusia online bertentangan dengan ketentuan rahasia data bank, namun demikian hal tersebut dapat dibijaksanai apabila terkait dengan kepentingan yang lebih besar (doelmatigheid), maka kedua ketentuan tersebut menjadi tidak bertentangan, dengan beberapa pertimbangan, yaitu:

1. Ketentuan mengenai kerahasiaan data bank ditujukan semata-mata agar data nasabah tidak diketahui secara luas oleh pihak luar/publik tanpa suatu tujuan tertentu yang dapat dibenarkan oleh hukum. (vide pasal 41, pasal 41a dan pasal 42 UU Perbankan).

2. Akses data agunan dalam pendaftaran fidusia secara online bertujuan untuk mengetahui ada tidaknya penjaminan sebelumnya terhadap objek yang akan difidusiakan. Dengan mengetahui data agunan maka dapat dipastikan nilai objek terhadap kredit yang di terima oleh pemberi fidusia. Dalam hal ini dapat ditegaskan bahwa akses data agunan pada dasarnya merupakan perlindungan hukum bagi kreditur dari kemungkinan adanya manipulasi data oleh debitur.

Mengacu pada hal-hal tersebut diatas 
dapat di tarik sebuah benang merah bahwa akses data agunan yang terdapat dalam pendaftaran fidusia secara online tidak bertentangan dengan ketentuan rahasia bank. Kaidah yang dapat ditarik adalah bahwa akses data agunan dalam i pendaftaran fidusia secara online dapat diperkenankan secara terbatas untuk penelusuran riwayat penjaminan atau suatu objek barang agunan.

\section{PENUTUP}

Data agunan yang menjadi bagian dalam aplikasi pendaftaran fidusia secara online tidak dapat dikatakan sebagai pelanggaran atas ketentuan rahasia bank sebagaimana dimaksud dalam pasal 40 UU Perbankan. Data agunan lebih merupakan kemudahan akses data yang sejatinya merupakan bentuk perlindungan hukum bagi para kreditur agar atas barang agunan tidak terdapat tumpang tindih jaminan.

\section{BIBLIOGRAFI}

Djumhana, Muhammad, 1996. Rahasia Bank (Ketentuan dan Penerapannya di Indonesia). Citra Aditya Bakti: Bandung. Fuady, Munir. 1992. Hukum Perbankan Modern. Citra Aditya Bakti: Bandung.

Hermansyah. 2009. Hukum Perbankan Nasional Indonesia, Kencana: Jakarta.

Kasmir. 2008. Bank dan Lembaga Keuangan Lainnya. Raja Grafindo Persada: Jakarta. Undang-Undang Nomor 10 Tahun 2008 tentang Perubahan Atas Undang-Undang No. 7 Tahun 1992 tentang Perbankan (Lembaran Negara Nomor 182 Tahun 1998, Tambahan Lembaran Negara Republik Indonesia No. 3790).

Undang-Undang Nomor 42 Tahun 1999 tentang Jaminan Fidusia, (Lembaran Negara Republik Indonesia Nomor 168 Tahun 1999, Tambahan Lembaran Negara
Republik Indonesia No. 3889).

http://ahu.go.id 